\title{
Gamification in learning process and its impact on entrepreneurial intention
}

\author{
Aries $^{a}$, Vional ${ }^{\mathrm{a}}$, Listya Ayu Saraswatia, Liana Wijaya ${ }^{\mathrm{a}}$ and Ridho Bramulya Ikhsan ${ }^{\text {a* }}$
}

\begin{tabular}{l}
${ }^{a}$ Management Department, BINUS Ont \\
\hline C H R O N I C L E \\
\hline Article history: \\
Received: September 52019 \\
Received in revised format: Sep- \\
tember 82019 \\
Accepted: October 23, 2019 \\
Available online: \\
October 23, 2019 \\
\hline Keywords: \\
Planned Behavior \\
Entrepreneurial Intentions \\
Long Distance Learning Program
\end{tabular}

Learning, Bina Nusantara University, Jakarta, Indonesia

\section{A B S T R A C T}

\begin{abstract}
Gamification is an educational approach to motivate and influence students' behaviors in learning with the intention of achieving learning outcomes. The primary objective of the study is to examine students' intentions to become entrepreneurs as an impact of gamification model learning in Entrepreneurship or Business Plan courses in BINUS ONLINE Learning. Data collection was carried out for 400 students who took Entrepreneurship and Business Plan courses for 1 month using questionnaires. The data was then analyzed using multiple linear regression approach. The result shows that attitude towards behavior (ATB), perceived behavior control (PBS), and subjective norms partially give positive impacts and they are significant to entrepreneurial intentions. Perceived behavioral control (PBC) is the dominant factor in forming entrepreneurial intentions for students.
\end{abstract}

\section{Introduction}

Indonesia economic growth in the fourth quarter of 2019 have reached 5.17 percent (BPS, 2019), thus it is believed to reduce the unemployment in Indonesia. However, the number of university graduates always increases every year. The government is expected to provide employment to fresh graduates. Universities, as institutions that expected to produce quality and competitive graduates, have larger contributions in giving solutions to unemployment problems. One of them is by teaching entrepreneurship and encouraging their students to have courage and competence to become entrepreneurs. Gamification model learning was developed and expected to motivate students to perceive learning outcomes, especially learning outcomes in Entrepreneurship and Business Plan courses. BINUS ONLINE Learning is one of higher education institutions in Indonesia which provides e-learning degree programs. The main challenge of teaching entrepreneurship for e-learning courses, such as entrepreneurship and business plan, is getting the interest and attention of students, so that they are motivated to apply the knowledge in real life entrepreneurship. Gamification model was studied in the context of entrepreneurship education (Gielnik et al., 2015). Management Program in BINUS Online Learning has implemented the gamification model in teaching Entrepreneurship and Business Plan courses. However, producing quality graduates who have entrepreneurial competence and behavior is still a big challenge for BINUS ONLINE Learning. Rauch and Hulsink (2015) have pointed out that many educators have developed alternative teaching models using games and simulation. However, empiric research is still scarce regarding the effects of gamification model in e-learning on performance, motivation, engagement, and development of desired student behaviors (Dichev \& Dicheva, 2017; Kristensson et al., 2017; Storbacka et al., 2016). Studies of entrepreneurial intention have been conducted by many scholars and rapidly evolving research, but there are no references specifically to the use of gamification in relation to entrepreneurial intention (Liñán \& Fayolle, 2015). Most publications about entrepreneurial intention concentrate on the relationship between entrepreneurship education and behaviors (Fayolle et al., 2016; Gielnik et al., 2015; Rauch \& Hulsink, 2015). This study develops results from Ruiz-Alba et al. (2019) research to examine students' entrepreneurial intentions. We

* Corresponding author.

E-mail address: ridho.bramulya.i@binus.ac.id (R. Bramulya Ikhsan) 
focus on students who learnt about entrepreneurship in Entrepreneurship and Business Plan e-learning courses using gamification method.

\section{Literature review}

\subsection{Entrepreneurship}

Entrepreneurship is linked to interest, either because people think they should start their own businesses or because they admire others who have done so. Understanding what entrepreneurship is and its concepts is fundamental (Fiet, 2001a, 2001b), but more importantly, understanding the difference between what and how it is implemented and how the people are trained (in the context of higher education institutions or universities) (Gielnik et al., 2015; Rauch \& Hulsink, 2015; Sidhu et al., 2015). Entrepreneurship in higher education institutions has been taught since 1970 and become compulsory course in business schools all over the world (Vesper \& Gartner, 1997). Still, teaching entrepreneurship is a contentious topic, hence the market creates entrepreneurship gamification training (Fayolle et al., 2016). In most educational settings, students only listen to lectures about theories (traditional teaching method) (Fiet, 2001a, 2001b; Kolb \& Kolb, 2005; Kolb, 1984). Many higher education institutions have evolved and grown out the traditional teaching method (Fry et al., 2009). This is also true in business contexts where trainings related to entrepreneurial skills have developed substantially since firstly introduced by Douglas and Shepherd (2002). It is also well implemented that learning with peers' interaction will transfer the feelings of experiments into a real context (Hamari, 2013; Ryan $\&$ Deci, 2000). Furthermore, most studies of entrepreneurship training are unable to develop longitudinal approach and direct relationship between training and entrepreneurship behaviors (Fayolle et al., 2016; Kamovich \& Foss, 2017). This study, therefore, focuses on the development of entrepreneurial intention as part of entrepreneurship behavior (Carr \& Sequeira, 2007; Kautonen et al., 2009; Kautonen et al., 2015; Schwarz Erich, 2009).

\subsection{Gamification}

Kapp and Coné (2012) explained that gamification is a method of learning using game-based mechanics, aesthetic, and cognitive to connect and motivate people, promote learning, and solve problems. Glover (2013) then concludes that gamification increases engagement of students that guarantees them to complete the lesson or task. Engagement here is the willingness to get involved and participated. Fredricks and McColskey (2012) add engagement is a meta-construction action that involved students' behaviors, emotions, and cognitive in learning. Games provide opportunities for players to make mistakes and restart the game when they make mistakes, so that they are not afraid of failure and are engaged in the games. Gamification works with appealing technology (Takahashi, 2010) to encourage users to partake in the desired behaviors (Stuart, 2010), to show the way to mastery and autonomy, to help solving problems, and to take advantage of psychological tendencies in engaging in games (Radoff, 2011). This study uses the concept of gamification as methods of learning aimed at entrepreneurship and business planning courses to examine the effect of gamification on the entrepreneurial intentions of students.

\subsection{Entrepreneurial Intentions (EI)}

Since the late 1980s, the definition of EI has been discussed in many literatures (Kautonen et al., 2015). EI refers to "the intention to start new businesses" (de Pillis \& Kathleen, 2007) and is therefore used as a measure of entrepreneurship. The academic community considered it appropriate to study EI using socio-cognitive frameworks (Zhao, Seibert, \& Hills, 2005). As an example is Theory of Planned Behavior (TPB) which is used to study relationship between intentions and behaviors (Krueger \& Carsrud, 1993; Krueger et al., 2000; Engle Robert \& Dimitriadi, 2010; Pihie \& Bagheri, 2011; Rauch \& Hulsink, 2015). According to TPB scholars, intentions are the single best indicator of most planned behavior, including entrepreneurial behavior (Kolvereid \& Isaksen, 2006; Krueger et al., 2000). Intentions are referred to "indication of how hard people are willing to try, how much effort they are planning to do in order to perform such behaviors" (Ajzen, 1991). This theory sees intentions as the results from attitudes (attitude towards behavior - ATB), perceived behavioral control (PBC), and subjective norms (SN). This study uses the TPB framework to predict EI. Ruiz-Alba et al. (2019) found positive impacts on ATB, PBS, and SN to EI in society through gamification training using online platform, which also regulated by gender indicators.

\section{Methodology}

This study adopted quantitative research strategy to address ATB, PBC, and SN impacts on EI of BINUS Online Learning students who study entrepreneurship and business plan using gamification learning method. Data collected by cross section for one month. Measurements for ATB, PBC, SN, and EI variables are referred to Ruiz-Alba et al. (2019) research with modifications as required. The population is 1562 students of Management Program (distance learning program) BINUS Online Learning. Sampling was performed using Slovin formula with 5\% alpha to obtain randomized 400 sample. The validity of collected primary data was tested using inter-item correlation approach, with score ranges ideal between $0.2-0.4$ (Piedmont, 2014). Test reliability was conducted using Cronbach Alpha with rule of thumb 0.7 (Nunnally, 1978). Data analysis method used multiple linear regression and BLUE (Best Linear Unbiased Estimator) test. 


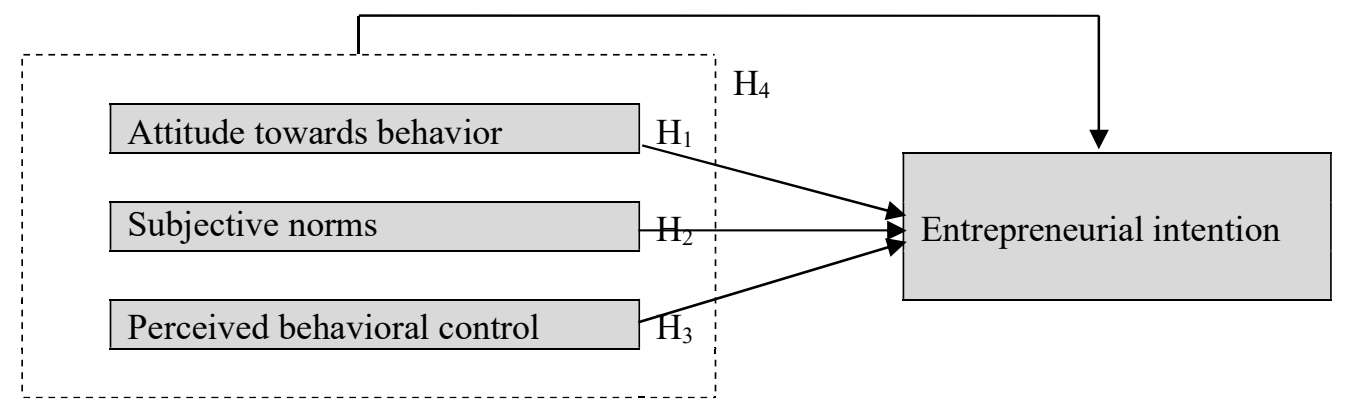

Fig. 1. Research model

\section{Results and discussion}

Multiple linear regression analysis is used to test the hypothesis with independent variables, including ATB, PBC, and SN, and with dependent variable, EI. First, the instrument was validity and reliability tested. The results of test validity of ATB, PBC, SN and EI variables are valid, because inter-item correlation has a value more than 0.2 , while the Cronbach Alpha value $>0.7$.

Table 1

EI Validity and Reliability Tests

\begin{tabular}{ccccccccc}
\hline \multirow{2}{*}{ Item } & \multicolumn{2}{c}{ Descriptive Statistics } & \multicolumn{5}{c}{ Inter-Item Correlation } \\
\cline { 2 - 9 } & Mean & $\mathrm{SD}$ & $\mathrm{EI}_{1}$ & $\mathrm{EI}_{2}$ & $\mathrm{EI}_{3}$ & $\mathrm{EI}_{4}$ & $\mathrm{EI}_{5}$ & $\mathrm{EI}_{6}$ \\
\hline $\mathrm{EI}_{1}$ & 4.3641 & .55489 & 1.000 & .623 & .531 & .591 & .546 & .601 \\
$\mathrm{EI}_{2}$ & 4.0733 & .78603 & .623 & 1.000 & .551 & .560 & .603 & .511 \\
$\mathrm{EI}_{3}$ & 3.9125 & .56720 & .531 & .551 & 1.000 & .364 & .539 & .463 \\
$\mathrm{EI}_{4}$ & 4.1702 & .63422 & .591 & .560 & .364 & 1.000 & .512 & .621 \\
$\mathrm{EI}_{5}$ & 4.1868 & .58058 & .546 & .603 & .539 & .512 & 1.000 & .587 \\
$\mathrm{EI}$ & 4.1726 & .63545 & .601 & .511 & .463 & .621 & .587 & 1.000 \\
\hline
\end{tabular}

Table 2

ATB Validity and Reliability Tests

\begin{tabular}{cccccc}
\hline \multirow{2}{*}{ Item } & \multicolumn{2}{c}{ Descriptive Statistics } & \multicolumn{3}{c}{ Inter-Item Correlation } \\
\cline { 2 - 6 } & Mean & SD & ATB1 & ATB2 & ATB3 \\
\hline $\mathrm{ATB}_{1}$ & 4.1726 & .52067 & 1.000 & .730 & .650 \\
$\mathrm{ATB}_{2}$ & 4.0946 & .56815 & .730 & 1.000 & .638 \\
$\mathrm{ATB}_{3}$ & 4.1939 & .53791 & .650 & .638 & 1.000 \\
\hline
\end{tabular}

Cronbach Alpha $=0.860>0.7$

Table 3

$\underline{\text { PBC Validity and Reliability Tests }}$

\begin{tabular}{|c|c|c|c|c|c|c|}
\hline \multirow{2}{*}{ Item } & \multicolumn{2}{|c|}{ Descriptive Statistics } & \multicolumn{4}{|c|}{ Inter-Item Correlation } \\
\hline & Mean & SD & Item 1 & Item 2 & Item3 & Item4 \\
\hline PBC1 & 3.8416 & .52966 & 1.000 & .644 & .418 & .499 \\
\hline PBC2 & 3.9740 & .54363 & .644 & 1.000 & .524 & .412 \\
\hline PBC3 & 3.9291 & .55901 & .418 & .524 & 1.000 & .654 \\
\hline PBC4 & 3.8132 & .55980 & .499 & .412 & .654 & 1.000 \\
\hline
\end{tabular}

Table 4

SN Validity and Reliability Tests

\begin{tabular}{cccccc}
\hline \multirow{2}{*}{ Item } & \multicolumn{2}{c}{ Descriptive Statistics } & \multicolumn{2}{c}{ Inter-Item Correlation } \\
\cline { 2 - 5 } & Mean & $\mathrm{SD}$ & Item1 & Item2 \\
\hline $\mathrm{SN}_{1}$ & 4.0709 & .62695 & 1.000 & .476 \\
$\mathrm{SN}_{2}$ & 4.0898 & .50257 & .476 & 1.000 \\
$\mathrm{SN}_{3}$ & 4.0307 & .65056 & .610 & .610 & .513 \\
\hline
\end{tabular}

Cronbach Alpha $=0.772>0.7$

Inter-item correlation value on IE is between of 0.364 and 0.623 , ATB is from 0.638 to 0.730 , PBC varies from 0.412 to 0.654 , and SN changes between 0.476 and 0.610. Therefore, question items can measure all the research variables. Cronbach Alpha values of all variables are more than 0.7 ; so that all items can be further evaluated. Secondly, we conducted the BLUE test on data normality, multicollinearity, and heteroscedasticity. The normality test was conducted using descriptive statistics to test 
skewness ratio and kurtosis ratio. Data is normally distributed if the ratio value is between -2 to 2 (George \& Mallery, 2016). If after multicollinearity testing's tolerance value is $<0.1$ or VIF (Variance Inflation Factor) $>10$, the symptoms of multicollinearity will occur (Robert, 2013). We conducted heteroscedasticity test using scatter plot.

Table 5

Normality Test

\begin{tabular}{|c|c|c|c|c|c|c|c|c|}
\hline \multirow{2}{*}{ Variable } & \multirow{2}{*}{$\frac{\mathrm{N}}{\text { Statistic }}$} & \multirow{2}{*}{$\begin{array}{c}\text { Mean } \\
\text { Statistic }\end{array}$} & \multicolumn{2}{|c|}{ Skewness } & \multirow{2}{*}{ Ratio } & \multicolumn{2}{|c|}{ Kurtosis } & \multirow{2}{*}{ Ratio } \\
\hline & & & Statistic & Std. Error & & Statistic & Std. Error & \\
\hline EI & 423 & 24.8794 & -.188 & .119 & -1.580 & -.342 & .237 & -1.443 \\
\hline ATB & 423 & 12.4610 & .107 & .119 & 0.899 & .437 & .237 & 1.844 \\
\hline PBC & 423 & 15.5579 & -.234 & .119 & -1.966 & -.214 & .237 & -0.903 \\
\hline SN & 423 & 12.1915 & -.057 & .119 & -0.479 & -.443 & .237 & -1.869 \\
\hline
\end{tabular}

Source: Collected primary data. 2019

Skewness ratio value is between -1.580 and 0.899 ; and Kurtosis ratio value is between -1.869 and 1.844 . As a result, the data were normally distributed. The tolerance value is greater than 0.1 ; and the VIF value is less than 10 . Therefore, the data is also declared free from multicollinearity symptom (see Table 6). The data is also free from the heteroscedasticity symptom because the points on the Scatterplot (see Fig. 2) spread above and below or around 0 and do not form certain patterns.

Table 6

Multicollinearity

\begin{tabular}{cccc}
\hline \multirow{2}{*}{ Variable } & \multicolumn{3}{c}{ Collinearity Statistics } \\
\cline { 2 - 4 } & Tolerance & 2.973 \\
ATB & .336 & 1.658 \\
PBC & .603 & 2.975 \\
SN & .336 & VIF \\
\hline
\end{tabular}

Source: Collected primary data. 2019

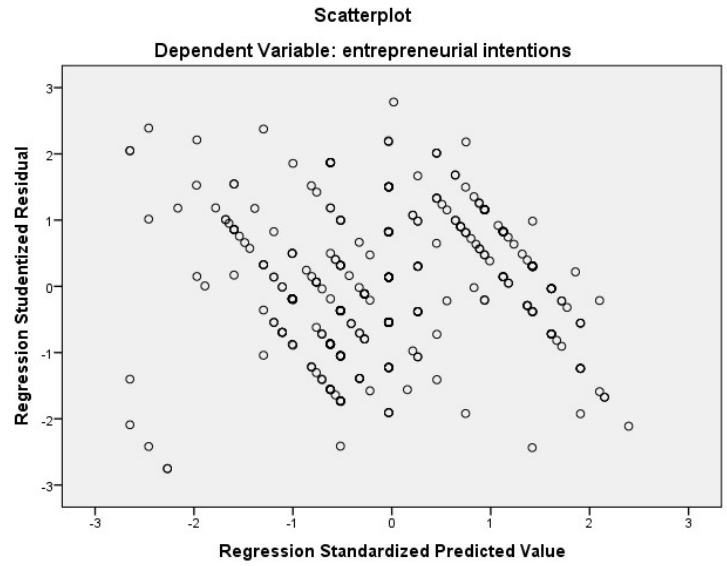

Fig. 2. Heteroscedasticity

Thirdly, multiple linear regression testing was conducted to answer the research questions. In multiple linear regression testing, there are 3 stages that are praised, namely t test (partial), F test (simultaneous) and R-Square.

Table 7

Regression Result

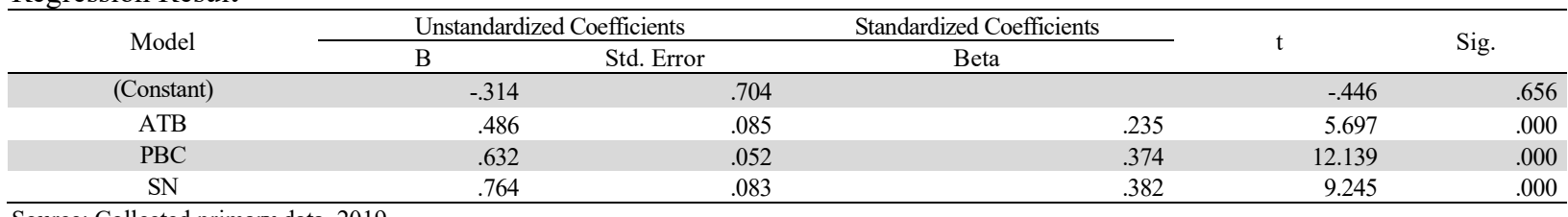

Source: Collected primary data. 2019

$$
E I=-0.314+0.486 X_{1}+0.632 X_{2}+0.764 X_{3}
$$

Sig t-value of ATB, PBC and SN is $0.000<0.05$. ATB, PBC, and SN have a strong and partly significant effect on EI. PBC becomes dominant factor in forming EI because it has the largest coefficient value. 
Table 8

The results of ANOVA test

\begin{tabular}{cccccc}
\hline Model & Sum of Squares & df & Mean Square & F & Sig. \\
\hline Regression & 2832.702 & 3 & 944.234 & 442.470 & .000 \\
Residual & 894.149 & 419 & 2.134 & & \\
\hline Total & 3726.851 & 422 & & & \\
\hline
\end{tabular}

Source: Collected primary data. 2019

Sig F-value is $0.000<0.05$. At the same time, thus, ATB, PBC, and SN impact EI. The extent of EI effect of ATB, PBC, and $\mathrm{SN}$ can be seen in the R-Square value (see Table 8). R-Square value is 0.760 , which means that $76 \%$ of EI is explained by $\mathrm{ATB}, \mathrm{PBC}$ and $\mathrm{SN}$ variables.

Table 9

Model summary

\begin{tabular}{ccccc}
\hline Model & $\mathrm{R}$ & $\mathrm{R}$ Square & Adjusted R Square & Std. Error of the Estimate \\
\hline 1 & $.872^{\mathrm{a}}$ & .760 & .758 & 1.46082 \\
\hline Source Primary data collected. 2019 & & &
\end{tabular}

Source: Primary data collected. 2019

Our research questions were answered. We conclude that ATB, PBC and SN have a positive and significant impact on the EI, both partially and simultaneously. PBC is the largest contributor to EI training, particularly for students of distance learning in BINUS Online Learning. This work confirms and empirically illustrates the hypothesis of the research by Ruiz-Alba et al. (2019) that the gamification learning model evaluated by ATB, PBC, and SN in the TBP definition shapes the desired EI behaviors, although this study does not regulate gender as a mediator. Such findings also lead to further work in the higher education field, in particular in distance education institutions, to the growth of entrepreneurial actions. The management implications of research findings are relevant for higher education institutions, in particular business schools, to apply the gamification model in both face-to-face and online classroom learning. With this model, students will understand more easily the material presented and foster a love for being an entrepreneur. This work has limits, so that it can be a source for further study. Our drawbacks are: (1) data collection is not retrospective, so behavioral improvements cannot be seen; (2) study is only valid to business schools, although it should also be contrasted to science schools.

\section{References}

Ajzen, I. (1991). The theory of planned behavior. Organizational Behavior and Human Decision Processes, 50(2), $179-211$.

BPS. (2019, Feb, 2019). Pertumbuhan Ekonomi Indonesia Triwulan IV-2018. Berita Resmi Statistik. Retrieved from https://www.bps.go.id/pressrelease/2019/02/06/1619/ekonomi-indonesia-2018-tumbuh-5-17-persen.html

Carr, J. C., \& Sequeira, J. M. (2007). Prior family business exposure as intergenerational influence and entrepreneurial intent: A Theory of Planned Behavior approach. Journal of Business Research, 60(10), 1090-1098.

de Pillis, E., \& Kathleen, R. (2007). The influence of personality traits and persuasive messages on entrepreneurial intention. Career Development International, 12(4), 382-396.

Dichev, C., \& Dicheva, D. (2017). Gamifying education: what is known, what is believed and what remains uncertain: a critical review. International Journal of Educational Technology in Higher Education, 14(1), 9. doi:10.1186/s41239-017-0042-5

Douglas, E. J., \& Shepherd, D. A. (2002). Self-Employment as a Career Choice: Attitudes, Entrepreneurial Intentions, and Utility Maximization. 26(3), 81-90.

Engle Robert, L., \& Dimitriadi, N. (2010). Entrepreneurial intent. International Journal of Entrepreneurial Behavior \& Research, 16(1), 35-57.

Fayolle, A., Verzat, C., \& Wapshott, R. (2016). In quest of legitimacy: The theoretical and methodological foundations of entrepreneurship education research. International Small Business Journal, 34(7), 895-904.

Fiet, J. O. (2001a). The pedagogical side of entrepreneurship theory. Journal of Business Venturing, 16(2), 101-117.

Fiet, J. O. (2001b). The theoretical side of teaching entrepreneurship. Journal of Business Venturing, 16(1), 1-24.

Fredricks, J. A., \& McColskey, W. (2012). The Measurement of Student Engagement: A Comparative Analysis of Various Methods and Student Self-report Instruments. In S. L. Christenson, A. L. Reschly, \& C. Wylie (Eds.), Handbook of Research on Student Engagement (pp. 763-782). Boston, MA: Springer US.

Fry, H., Ketteridge, S., \& Marshall, S. (2009). A handbook for teaching and learning in higher education: Enhancing academic practice. United Kingdom: Routledge.

George, D., \& Mallery, P. (2016). IBM SPSS statistics 23 step by step: A simple guide and reference (14, revised ed.): Routledge.

Gielnik, M., Frese, M., Kahara-Kawuki, A., Katono, I. W., Kyejjusa, S., Ngoma, M., \& Dlugosch, T. J. (2015). Action and Action-Regulation in Entrepreneurship: Evaluating a Student Training for Promoting Entrepreneurship. Academy of Management Learning \& Education, 14(1), 69-94. doi:10.5465/amle.2012.0107

Glover, I. (2013). Play As You Learn: Gamification as a Technique for Motivating Learners. Paper presented at the EdMedia + Innovate Learning 2013, Victoria, Canada. https://www.learntechlib.org/p/112246

Hamari, J. (2013). Transforming homo economicus into homo ludens: A field experiment on gamification in a utilitarian peerto-peer trading service. Electronic Commerce Research and Applications, 12(4), 236-245. 
Kamovich, U., \& Foss, L. (2017). In Search of Alignment: A Review of Impact Studies in Entrepreneurship Education \%J Education Research International. 2017, 15. doi:10.1155/2017/1450102

Kapp, K., \& Coné, J. (2012). What every chief learning officer needs to know about games and gamification for learning. Department of Instructional Technology and Institute for Interactive Technologies.

Kautonen, T., Tornikoski, E. T., \& Kibler, E. (2009). Entrepreneurial intentions in the third age: the impact of perceived age norms. Small Business Economics, 37(2), 219-234.

Kautonen, T., Van Gelderen, M., \& Fink, M. (2015). Robustness of the Theory of Planned Behavior in Predicting Entrepreneurial Intentions and Actions. 39(3), 655-674. doi:10.1111/etap.12056

Kolb, A. Y., \& Kolb, D. A. (2005). Learning Styles and Learning Spaces: Enhancing Experiential Learning in Higher Education. Academy of Management Learning \& Education, 4(2), 193-212. doi:10.5465/amle.2005.17268566

Kolb, D., A. (1984). Experiential learning: Experience as the source of learning and development. Englewood Cliffs, NJ: Prentice Hall.

Kolvereid, L., \& Isaksen, E. (2006). New business start-up and subsequent entry into self-employment. Journal of Business Venturing, 21(6), 866-885.

Kristensson, P., Wästlund, E., \& Söderlund, M. (2017). Influencing consumers to choose environment friendly offerings: Evidence from field experiments. Journal of Business Research, 76, 89-97.

Krueger, N. F., \& Carsrud, A. L. (1993). Entrepreneurial intentions: Applying the theory of planned behaviour. Entrepreneurship \& Regional Development, 5(4), 315-330.

Krueger, N. F., Reilly, M. D., \& Carsrud, A. L. (2000). Competing models of entrepreneurial intentions. Journal of Business Venturing, 15(5), 411-432.

Liñán, F., \& Fayolle, A. (2015). A systematic literature review on entrepreneurial intentions: citation, thematic analyses, and research agenda. International Entrepreneurship Management Journal, 11(4), 907-933.

Nunnally, C. (1978). Psychometric Theory (2 ed.). The University of Michigan: McGraw-Hill.

Piedmont, R. L. (2014). Inter-item Correlations. In A. C. Michalos (Ed.), Encyclopedia of Quality of Life and Well-Being Research (pp. 3303-3304). Dordrecht: Springer Netherlands.

Pihie, Z. L., \& Bagheri, A. (2011). Malay secondary school students' entrepreneurial attitude orientation and entrepreneurial selfefficacy: A descriptive study. Journal of Applied Sciences, 11(2), 316-322.

Radoff, J. (2011). Game on: Energize your business with social media games: John Wiley \& Sons.

Rauch, A., \& Hulsink, W. (2015). Putting Entrepreneurship Education Where the Intention to Act Lies: An Investigation Into the Impact of Entrepreneurship Education on Entrepreneurial Behavior. Academy of Management Learning \& Education, 14(2), 187-204.

Robert, H. (2013). Handbook of Univariate and Multivariate Data Analysis with IBM SPSS, Second Edition (2, revised ed.): CRC Press.

Ruiz-Alba, J. L., Soares, A., Rodríguez-Molina, M. A., \& Banoun, A. (2019). Gamification and entrepreneurial intentions. Journal of Small Business Enterprise Development. doi:https://doi.org/10.1108/JSBED-09-2018-0266

Ryan, R. M., \& Deci, E. L. (2000). Self-determination theory and the facilitation of intrinsic motivation, social development, and well-being. American psychologist, 55(1), 68.

Schwarz Erich, J. (2009). The effects of attitudes and perceived environment conditions on students' entrepreneurial intent. Education + Training, 51(4), 272-291.

Sidhu, I., Johnsson, C., Singer, K., \& Suoranta, M. (2015). A game-based method for teaching entrepreneurship. Applied Innovation Review, 1(1), 51-65.

Storbacka, K., Brodie, R. J., Böhmann, T., Maglio, P. P., \& Nenonen, S. (2016). Actor engagement as a microfoundation for value co-creation. Journal of Business Research, 69(8), 3008-3017.

Stuart, K. (2010, 19 Sept). 3D games enter a new generation. The Observer Games. Retrieved from https://www.theguardian.com/technology/2010/sep/19/3d-games-xbox-playstation

Takahashi, D. (2010). Gamification gets its own conference. Paper presented at the Venture Beat.[Online]. Available: http://venturebeat. com/2010/09/30/gamification-gets-its-own-conference.

Vesper, K. H., \& Gartner, W. B. (1997). Measuring progress in entrepreneurship education. Journal of Business Venturing, 12(5), 403-421. doi:https://doi.org/10.1016/S0883-9026(97)00009-8

Zhao, H., Seibert, S. E., \& Hills, G. E. (2005). The mediating role of self-efficacy in the development of entrepreneurial intentions. Journal of applied psychology, 90(6), 1265.

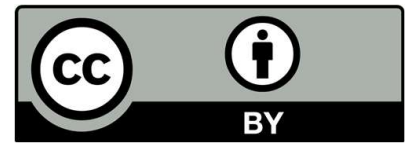

(C) 2020 by the authors; licensee Growing Science, Canada. This is an open access article distributed under the terms and conditions of the Creative Commons Attribution (CC-BY) license (http://creativecommons.org/licenses/by/4.0/). 